\title{
Pemberdayaan Ibu-Ibu PKK Melalui Usaha Rumah Tangga pada Masa Pandemi Covid
}

\author{
Mei Indrawati \\ Universitas Wijaya Putra \\ meiindrawati@uwp.ac.id
}

\begin{abstract}
Abstrak
Kebutuhan dan keinginan manusia dari hari ke hari semakin bertambah dan semakin beraneka ragam. Tidak terkecuali dengan kebutuhan rumah tangga. Dengan kondisi pandemi saat ini menjadi kekhawatiran tersendiri bagi siapa saja untuk berinteraksi dengan orang lain, apalagi ketika kita ingin berbelanja, entah ke pasar ataupun ke mall, dimana kedua tempat tersebut merupakan lokasi yang berpeluang besar sebagai tempat penyebaran covid 19.

Dalam rangka menangkap peluang dan memenuhi kebutuhan rumah tangga tanpa harus keluar rumah, maka ibu-ibu PKK melakukan kegiatan yang produktif yang sekaligus dapat meningkatkan income rumah tangga. Kegiatan pengabdian kepada masyarakat ini dilaksanakan di Kelurahan Lontar Kota Surabaya.

Kegiatan ini dilaksanakan dengan tujuan : 1) Meningkatkan pendapatan rumah tangga; 2) Memunculkan jiwa wirausaha; dan 3) Meningkatkan intensitas bersosialisasi di kalangan warga. Pelaksanaan kegiatan ini menggunakan : metode pelatihan dan metode pendampingan. Metode pelatihan meliputi : 1) Pelatihan kewirausahaan; 2) Pelatihan pemasaran produk dan 3) Pelatihan pembukuan sederhana. Metode pendampingan meliputi : 1) Pendampingan penguatan kegiatan pemasaran produk dan 2) Pendampingan penguatan kegiatan tertib administrasi.

Sedangkan hasil dari kegiatan ini adalah : 1) Meningkatnya pendapatan rumah tangga antara Rp. 200.000 sampai dengan Rp. 500.000 per bulan; 2) Munculnya jiwa wirausaha bagi sebagian warga Kelurahan Lontar Kota Surabaya; dan 3) Tersusunnya pembukuan sederhana; dan 4) Meningkatnya intensitas bersosialisasi di kalangan warga.
\end{abstract}

Kata Kunci : Belanja antar tetangga, covid 19, kewirausahaan, pemberdayaan, PKK

\section{PENDAHULUAN}

Pandemi Covid-19 yang berlangsung sejak awal tahun 2020 telah memukul berbagai sektor perekonomian dan sosial di Indonesia (Kompas.com, 29 Mei 2020). Indonesia mengkonfirmasi kasus pertama infeksi virus corona penyebab Covid-19 pada awal Maret 2020. Hingga saat ini, masih belum diketahui kapan situasi ini akan berakhir. Virus ini memporak-porandakan ekonomi dan peradaban masyarakat dunia. Ekonomi rakyat terkoyak dengan serangan virus corona yang memaksa mereka membatasi bahkan menghentikan aktivitas ekonominya (Kompas.com, 11 Agustus 2020).

Hampir seluruh sektor terdampak, tak hanya kesehatan tapi juga kehidupan seharihari. Timbul berbagai permasalahan sosial mulai dari maraknya Pemutusan Hubungan Kerja (PHK) atau merumahkan pekerja untuk sementara waktu, banyak masyarakat yang mengalami pemotongan gaji, ekonomi mulai menurun. Hal tersebut dikarenakan pelaku usaha melakukan efisiensi untuk

Ekonomi, Sosial, dan Budaya 1035 
menekan kerugian, akibatnya banyak pekerja yang dirumahkan atau bahkan diberhentikan (PHK). Berdasarkan data Kementerian Ketenagakerjaan per 7 April 2020, akibat pandemi Covid-19, tercatat sebanyak 39.977 perusahaan di sektor formal yang memilih merumahkan dan melakukan PHK terhadap pekerjanya (Kompas.com, 11 Agustus 2020). Kemenaker dan BPJS Ketenagakerjaan mencatat sekitar 2,8 juta pekerja terkena dampak pandemi Covid-19. Mereka terdiri dari 1,7 juta pekerja formal dirumahkan dan 749,4 ribu di-PHK. Selain itu, terdapat 282 pekerja informal yang usahanya terganggu. Hal ini akibat terhentinya operasional perusahaan tempat mereka bekerja (Kompas.com, 29 Mei 2020). Jadi dampak ini secara masif telah meluluh lantahkan sendi-sendi sosial dan perekonomian Indonesia. Pandemi Covid-19 telah membawa kesengsaraan terhadap para pekerja formal dan informal.

Keluarga-keluarga di Kelurahan Lontar seperti halnya keluarga-keluarga di wilayah lain, sebagai bagian dari masyarakat yang terdampak dari pandemi juga merasakan takut dan meningkatkan kewaspadaan sehingga mereka memilih untuk tetap di rumah dan membatasi atau bahkan tidak melakukan aktivitas di luar rumah sama sekali. Akibatnya guncangan ekonomi mulai dirasakan. Di satu sisi mereka dituntut untuk bisa menghadapi situasi dan kondisi agar tetap survive, di sisi lain mereka dihadapkan pada beban tanggungan seperti biaya hidup sehari-hari, baik konsumsi maupun biaya-biaya lain termasuk cicilan kredit. Demi mengatasi masalah ekonomi serta kekhawatiran untuk berinteraksi dengan orang lain, apalagi ketika kita ingin berbelanja, entah ke pasar ataupun ke mall, dimana kedua tempat tersebut berpotensi sangat besar sebagai tempat penyebaran covid 19 dan sekaligus mempererat kebersamaan diantara para warga di Kelurahan Lontar, maka sebagian warga berinisiatif melakukan aktivitas yang cukup produktif yang sekaligus dapat meningkatkan income rumah tangga mereka, yang mereka namakan sendiri sebagai Gerakan Belanja Antar Tetangga. Mereka sangat sadar bahwa kegiatan ini sedikit banyak dapat menjadi solusi bagi permasalahan yang mereka hadapi, yaitu meningkatkan pendapatan/income rumah tangga dan mengurangi aktifitas keluar rumah dalam rangka memutus rantai covid 19. Mereka berusaha untuk memberdayakan diri sendiri dan sekaligus memupuk jiwa wirausaha. Ibu-ibu PKK ini menangkap peluang dan memenuhi kebutuhan rumah tangga tanpa harus keluar rumah.

Urgensi dan Rasionalisasi Kegiatan

Kegiatan pengabdian kepada masyarakat ini memiliki tingkat urgensi yang sangat tinggi bagi keberlangsungan perekonomian masyarakat pada masa pandemi dan dapat dilanjutkan pada kondisi new normal. Kegiatan ini juga dapat memotivasi masyarakat agar lebih berdaya serta menumbuhkan jiwa wirausaha bagi ibu-ibu PKK di Kelurahan Lontar Kota Surabaya.

Tujuan

Tujuan dilaksanakannya kegiatan pengabdian kepada masyarakat ini : 1) Peningkatan pendapatan rumah tangga di masa pandemi; 2) Peningkatan jiwa wirausaha bagi ibu-ibu PKK; dan 3) Meningkatkan intensitas bersosialisasi di kalangan warga Kelurahan Lontar Kota Surabaya.

\section{Rencana Penanganan Masalah}

Untuk menangani masalah yang ada pada kegiatan ibu-ibu PKK di Kelurahan Lontar ini menggunakan : metode pelatihan dan metode pendampingan.

Tinjauan Pustaka

Pemberdayaan Masyarakat

Pemberdayaan adalah upaya untuk meningkatkan kemampuan seseorang atau kelompok sehingga mampu melaksanakan tugas dan kewenangannya sebagaimana tuntutan kinerja tugas. Pemberdayaan merupakan proses yang dapat dilakukan melalui berbagai upaya, seperti pemberian wewenang, meningkatkan partisipasi, memberikan kepercayaan sehingga setiap orang atau kelompok dapat memahami apa yang akan dikerjakannya, yang pada akhirnya akan berimplikasi pada peningkatan pencapaian tujuan secara efektif dan efisien (Mahidin, 2006). Menurut Mubarak (2010) pemberdayaan masyarakat dapat diartikan

\begin{tabular}{l|l} 
Ekonomi, Sosial, dan Budaya & 1036
\end{tabular} 
sebagai upaya untuk memulihkan atau meningkatkan kemampuan suatu komunitas untuk mampu berbuat sesuai dengan harkat dan martabat mereka dalam melaksanakan hak-hak dan tanggung jawabnya selaku anggota masyarakat. Sedangkan Suharto (2015) mengemukakan bahwa pemberdayaan merujuk pada kemampuan seseorang atau kelompok sehingga mereka memiliki kemampuan dalam memenuhi kebutuhan dasarnya, menjangkau sumber-sumber produktif yang memungkinkan mereka dapat meningkatkan pendapatannya dan memperoleh barang dan jasa yang mereka butuhkan serta berpartisipasi dalam proses pembangunan. Pemberdayaan adalah sebuah kesinambungan untuk menempatkan masyarakat lebih proaktif dalam menentukan arah kemajuan dalam komunitasnyan sendiri. Artinya program pemberdayaan tidak bisa hanya dilakukan dalam satu siklus saja dan berhenti pada satu tahapan tertentu, akan tetapi harus terus berkesinambungan dan kualitasnya terus meningkat dari satu tahapan ke tahapan berikutnya. Tahapan-tahapan yang ada dalam siklus pemberdayaan masyarakat adalah : 1) Keinginan dari masyarakat sendiri untuk berubah menjadi lebih baik; 2) Masyarakat diharapkan mampu melepaskan halanganhalangan atau faktor-faktor yang bersifat resistensi terhadap kemajuan dalam dirinya dan komunitasnya; 3) Masyarakat diharapkan sudah menerima kebebasan tambahan dan merasa memiliki tanggung jawab dalam dirinya dan komunitasnya; 4) Upaya untuk mengembangkan peran dan batas tanggung jawab yang lebih luas, dan memiliki minat dan motivasi untuk melakukan pekerjaan dengan lebih baik; 5) Hasil nyata dari pemberdayaan mulai terlihat, peningkatan rasa memiliki dan menghasilkan kinerja yang lebih baik; 6) Terjadi perubahan perilaku dan kesan terhadap dirinya; dan 7) Masyarakat yang telah berhasil memberdayakan dirinya, tertantang untuk menghasilkan kinerja yang lebih baik (Mubarak, 2010). Jadi pemberdayaan masyarakat adalah sebuah konsep pembangunan ekonomi yang merangkum nilainilai sosial. Pemberdayaan adalah sebuah usaha berkesinambungan untuk menempatkan masyarakat menjadi lebih proaktif dalam menentukan arah kemajuan dalam komunitasnya sendiri. Pemberdayaan memiliki tujuan melepaskan belenggu kemiskinan dan keterbelakangan serta memperkuat posisi lapisan masyarakat. Jadi dari sisi proses, pemberdayaan adalah serangkaian kegiatan untuk memperkuat keberdayaan kelompok lemah dalam masyarakat, termasuk individuindividu yang miskin. Sebagai tujuan pemberdayaan merujuk pada keadaan atau hasil yang ingin dicapai oleh sebuah perubahan sosial, yaitu masyarakat yang berdaya, mempunyai pengetahuan dan kemampuan dalam memenuhi kebutuhan hidupnya baik yang bersifat fisik, ekonomi maupun sosial, seperti memiliki kepercayaan diri, mampu menyampaikan aspirasi, mempunyai mata pencaharian, berpartisipasi dalam kegiatan sosial, dan mandiri dalam melaksanakan tugastugas kehidupannya (Sipahelut, 2010).

Kewirausahaan

Zimmerer, 2009, menjelaskan kewirausahaan (entrepreneurship) adalah suatu proses penerapan kreativitas dan inovasi dalam memecahkan persoalan dan menemukan peluang untuk memperbaiki kehidupan atau usaha. Wijatno (2009) menyatakan bahwa kewirausahaan adalah hasil dari proses menerapkan kreativitas dan inovasi secara sistematis dan teratur terhadap kebutuhan dan peluang yang ada untuk memenuhi kebutuhan konsumen atau memecahkan masalah konsumen. Menurut Prawiro dalam Suryana (2009) kewirausahaan merupakan suatu nilai yang diperlukan untuk memulai suatu usaha (start-up phase) dan perkembangan usaha (venture growth). Sedangkan Siagian dan Asfahani dalam Ananda dan Rafida (2016) mendefinisikan bahwa kewirausahaan adalah semangat, perilaku dan kemampuan untuk memberikan tanggapan yang positif terhadap peluang memperoleh keuntungan untuk diri sendiri atau pelayanan yang lebih baik pada pelanggan/masyarakat, dengan selalu berusaha mencari dan melayani pelanggan lebih banyak dan lebih baik, serta lebih efisien, melalui keberanian mengambil resiko, kreativitas dan inovasi serta kemampuan manajemen menyedikan produk yang klebih bermanfaat dan menerapkan cara kerja. Jadi inti dari kewirausahaan adalah kemampuan untuk 
menciptakan sesuatu yang baru dan berbeda (create new and differrent) melalui aktivitas berfikir kreatif dan inovatif. Pada kewirausahaan seseorang atau sekelompok orang berproses memikul resiko ekonomi untuk menciptakan organisasi baru yang akan mengeksploitasi teknologi baru atau proses yang inovatif yang menghasilkan nilai untuk orang lain. Sehiungga kewirausahaan (entrepreneurship) dapat kita pahami bahwa : 1) sikap jiwa dan kemampuan untuk menciptakan sesuatu yang baru yang sangat bernilai dan berguna bagi dirinya dan orang lain; 2) sikap mental dan jiwa yang selalu aktif atau kreatif dalam berusaha dalam rangka menciptakan pendapatan dalam kegiatan usahanya atau kiprahnya; 3) usaha menciptakan nilai tambah dengan jalan mengkombinasikan sumber-sumber melalui cara-cara baru dan berbeda untuk memenangkan persaingan; dan 4) suatu proses dalam mengerjakan sesuatu yang baru (creative) dan sesuatu yang berbeda (inovative) yang bermanfaat bagi konsumen dan memberi nilai lebih.

Wirausaha (entrepreneur) menurut Ananda dan Rafida, 2016, adalah kemampuan untuk menciptakan, mencari dan memanfaatkan peluang dalam menuju apa yang diinginkan sesuai dengan yang diidealkan. Steinhoff dan Burgess dalam Ananda dan Rafida (2016) mengatakan bahwa entrepreneur adalah orang yang mengorganisir, mengelola/menjalankan dan berani menanggung resiko untuk menciptakan usaha baru dan peluang berusaha. Entrepreneur adalah mereka yang bisa menciptakan kerja bagi orang lain dengan berswadaya. Drucker (1993) dalam Ananda dan Rafida (2016) menyatakan bahwa entrepreneur adalah orang yang memiliki kemampuan untuk menciptakan sesuatu yang baru, berbeda dari yang lain atau mampu menciptkan sesuatu yang berbeda dengan yang sudah ada sebelumnya. Jadi seorang entrepreneur adalah orang yang melihat adanya peluang kemudian menciptakan sebuah organisasi untuk memanfaatkan peluang tersebut. Sehingga dapat kita pahami bahwa entrepreneur (wirausaha) adalah : 1) seseorang yang bebas dan memiliki kemampuan untuk hidup mandiri dalam menjalankan kegiatan usahanya atau bisnisnya atau hidupnya; 2) seseorang yang bebas merancang, menentukan pengelolaan dan mengendalikan usahanya; dan 2) seseorang yang terampil memanfaatkan peluang dalam mengembangkan usahanya dengan tujuan untuk meningkatkan kehidupannya.

\section{METODE}

Untuk menangani masalah ekonomi rumah tangga akibat / dampak pandemi covid 19 yang ada di Kelurahan Lontar Kota Surabaya menggunakan dua metode yaitu metode pelatihan dan pendampingan. Metode pelatihan meliputi : 1) Pelatihan kewirausahaan; 2) Pelatihan pemasaran produk; dan 3) Pelatihan pembukuan sederhana. Metode pendampingan meliputi : 1) Pendampingan penguatan kegiatan pemasaran produk dan 2) Pendampingan penguatan kegiatan tertib administrasi.

Metode Pelatihan. Metode pelatihan ini diawali dengan diadakannya kegiatan penyuluhan tentang kewirausahaan, pemasaran produk dan pembukuan sederhana. Setelah dilakukan penyuluhan, kemudian dilanjutkan dengan kegiatan simulasi.

Metode Pendampingan. Setelah dilakukannya kegiatan pelatihan kewirausahaan, pemasaran produk dan pelatihan pembukuan sederhana, selanjutnya dilakukan metode pendampingan. Kegiatan pendampingan ini meliputi pendampingan penguatan kegiatan pemasaran produk dan pendampingan penguatan kegiatan tertib administrasi. Kegiatan pendampingan pemasaran produk meliputi pemetaan produk yang dibutuhkan oleh sektor rumah tangga, disain foto tampilan promosi produk, dan strategi menarik pembeli. Kegiatan pendampingan penguatan tertib administrasi adalah menyusun buku yang diperlukan dalam aliran keluar dan masuknya uang serta barang. 
Langkah-langkah sistematis yang dilakukan dalam pelaksanaan kegiatan pengabdian kepada masyarakat ini sebagai berikut :

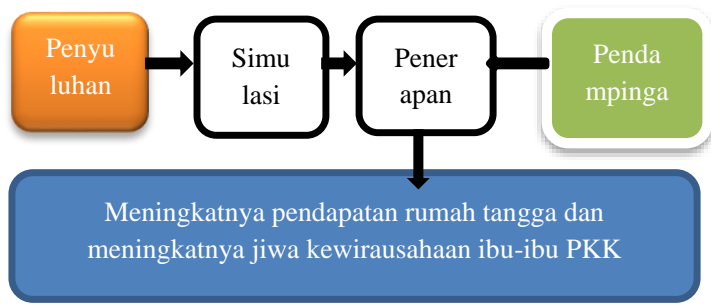

Gambar 1. Pelaksanaan kegiatan pengabdian kepada masyarakat pada Ibu-Ibu PKK di Kelurahan Lontar Kota Surabaya

\section{HASIL DAN PEMBAHASAN}

Terlaksananya kegiatan Belanja Antar Tetangga diawali dari adanya fasilitas yang diberikan oleh tim PKK yang pada saat arisan PKK membolehkan anggotanya untuk menjual barang ke ibu-ibu PKK yang lain dengan kewajiban membayar sebesar lima ribu rupiah untuk dimasukkan ke dalam kas PKK. Namun kegiatan tersebut sifatnya adalah insidental saja, artinya tidak setiap pertemuan PKK ada anggota PKK yang menjual barang. Adanya pandemi yang sangat berdampak pada ekonomi rumah tangga dan kekhawatiran dari para ibu untuk keluar rumah untuk memenuhi kebutuhan barang rumah tangga sehari-hari menjadi alasan tercetusnya gagasan dibentuknya kegiatan Belanja Antar Tetangga. Ditunjang dengan adanya sosial media berupa WhatsApp yang sangat mempermudah kegiatan Belanja Antar Tetangga ini. Siapa saja diperbolehkan menawarkan produknya di grup WhatsApp tersebut. Secara umum barangbarang yang ditawarkan merupakan kebutuhan dapur dan makanan dengan harga yang sangat terjangkau untuk kondisi saat pandemi ini. Barang yang diperdagangkan tersebut, ada yang memang barang dagangan mereka sendiri, namun ada kalanya para ibu hanya menjadi perantara dari barang dagangan milik orang lain. Berikut merupakan contoh produk yang dijual pada kegiatan Belanja Antar Tetangga yang ditawarkan melalui grup WhatsApp.
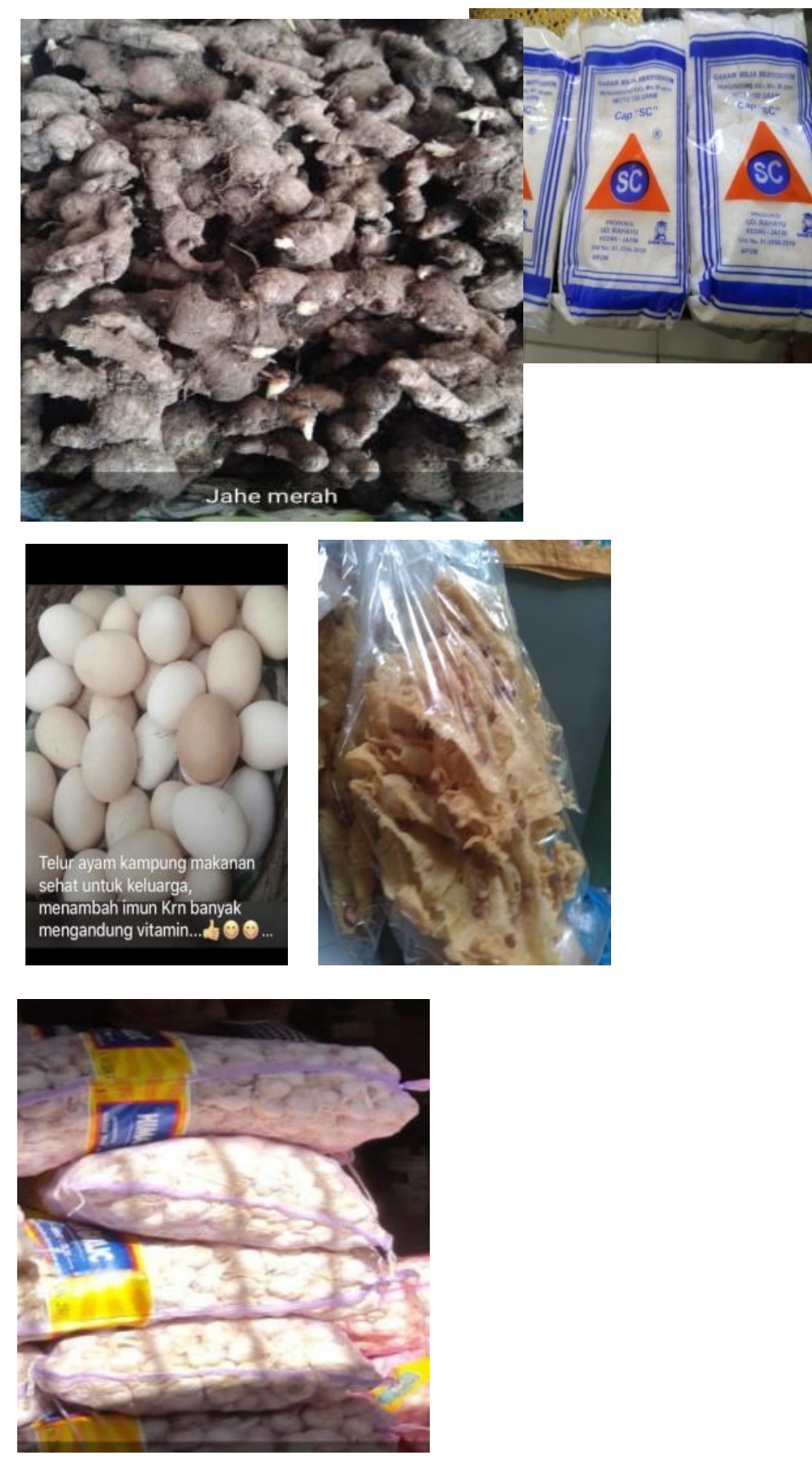

Ekonomi, Sosial, dan Budaya 1039 


\section{IFFM \\ CBRI}

Prosiding PKM-CSR, Vol. 3 (2020)

e-ISSN: 2655-3570
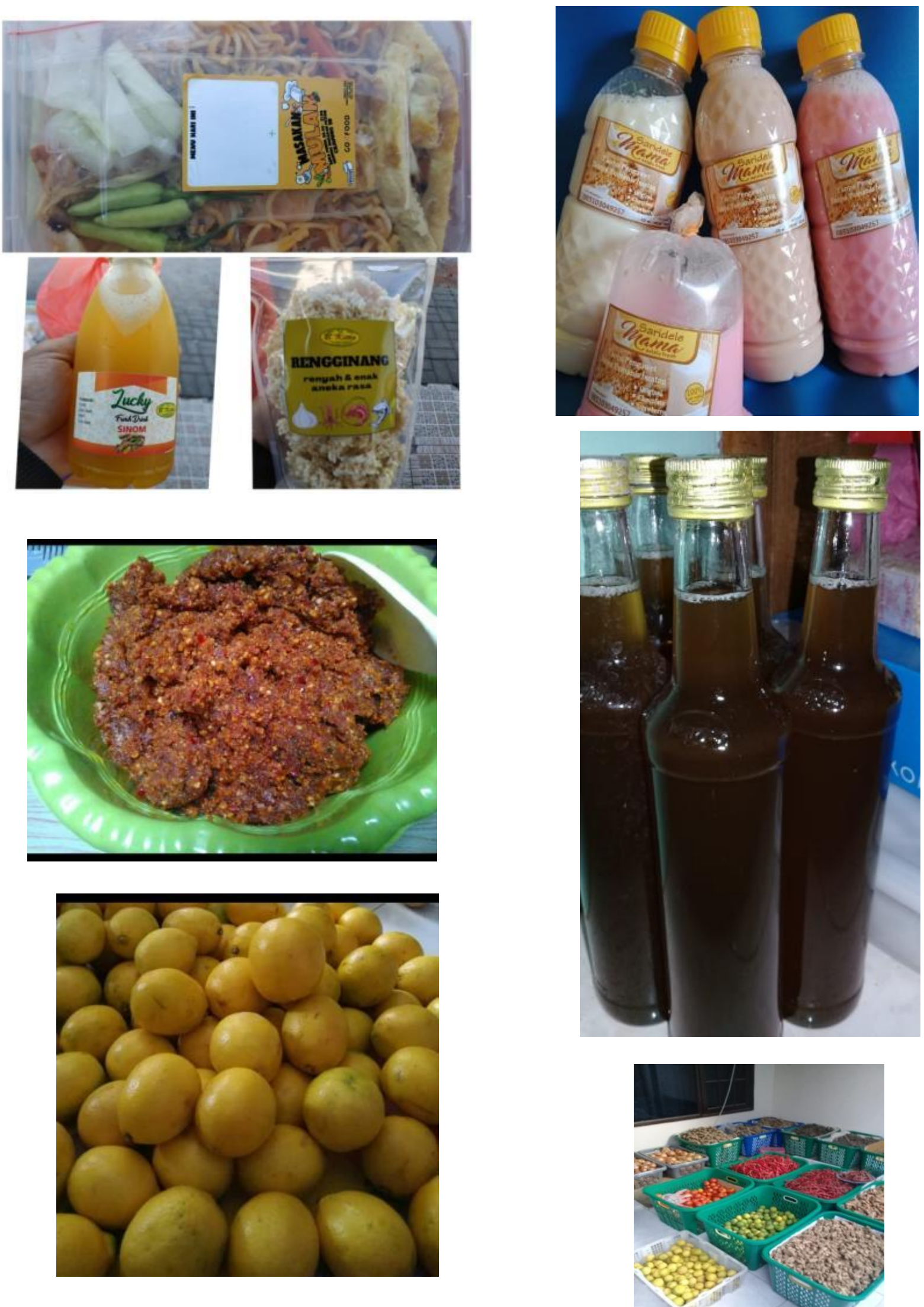

Ekonomi, Sosial, dan Budaya 1040 
Gambar 2. Barang-Barang yang Ditawarkan melalui WhatsApp pada Kegiatan Belanja Antar Tetangga

Berikut adalah transaksi yang terjadi antara penjual dengan pembeli yang kesemuanya dilakukan di lingkungan Kelurahan Lontar Kota Surabaya. Pembayaran dilakukan secara tunai karena jumlahnya tidak banyak dan lokasinya tidak jauh. Sehingga baik penjual maupun pembeli sama-sama diuntungkan dan sama-sama dimudahkan. Pembeli tidak perlu keluar rumah, karena mereka memesan barang lewat media WhatsApp dan barang diantar ke rumah pembeli. Sementara penjual memperoleh keuntungan dari barang yang dijualnya.

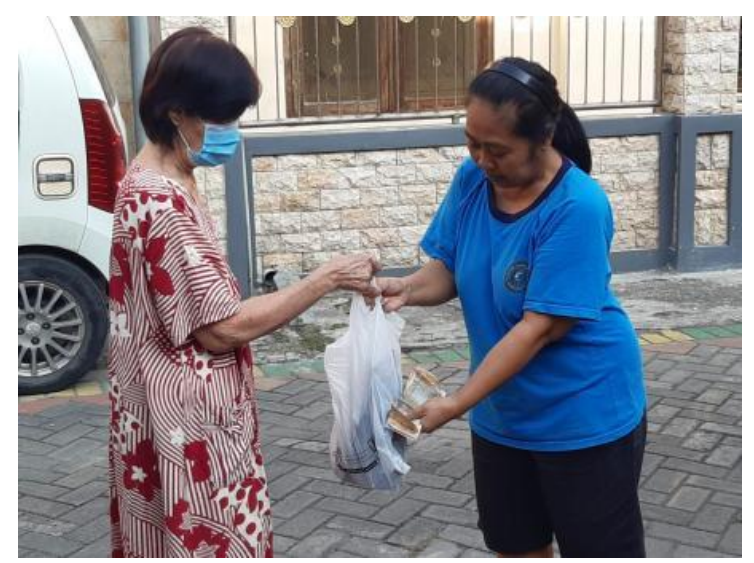

Gambar 3. Transaksi Antar Penjual dan Pembeli

Sisi lain dari adanya kegiatan Belanja Antar Tetangga adalah meningkatnya intensitas bersosialisasi antar warga. Karena barang diantar ke rumah pemesan oleh penjual. Mereka bisa saling menyapa. Dari kegiatan Belanja Antar Tetangga dapat meringankan warga yang kesulitan ekonomi dengan menambah pendapatan rumah tangga antara Rp. 200.000 sampai dengan Rp. 500.000 per bulan. Jadi dengan kegiatan ini telah muncul jiwa wirausaha bagi ibu-ibu PKK Kelurahan Lontar Kota Surabaya. Mereka mampu menangkap peluang yang ada di depan mereka.

Dengan adanya program penyuluhan dan pelatihan tentang kewirausahaan, maka ibu-ibu PKK menjadi semakin termotivasi untuk meningkatkan usaha mereka dengan lebih profesional. Jiwa entrepreneur semakin tumbuh. Hal ini sesuai dengan hasil pengabdian kepada masyarakat yang dilakukan oleh Indrawati (2019). Mereka semakin optimis bahwa dengan Kegiatan Belanja Antar Tetangga dapat meningkatkan pendapatan rumah tangga mereka, sehingga dapat meringankan beban keluarga. Ibu-ibu PKK memiliki tekad bahwa kegiatan ini terus dijalankan meskipun kelak pandemi covid 19 sudah berlalu. Karena mereka sudah merasakan manfaat dari kegiatan yang mereka jalankan selama ini. Penyuluhan tentang pemasaran produk, membuat mereka paham bahwa tidak serta merta mereka menawarkan produknya. Mereka menjual / menawarkan produk dimana barang tersebut memang dibutuhkan / diinginkan oleh banyak keluarga. Sehingga barang mereka cepat terjual dan perputaran modal mereka menjadi cepat. Ujung-ujungnya adalah keuntungan menjadi semakin cepat diperoleh. Penyuluhan pembukuan sederhana juga merubah kinerja mereka, karena dengan semakin tertibnya pencatatan, maka akan semakin mudah untuk mengontrol arus keluar dan masuknya uang dan barang. Berapa uang yang dibelanjakan untuk pengadaan barang dagangan dan berapa uang yang diperoleh dari hasil penjualan per harinya dan kemudian mereka total selama satu minggu satu kali. Dari pencatatan tersebut bisa langsung diketahui berapa keuntungan yang mereka dapatkan. Dari pencatatan sederhana itu juga, mereka dapat membuat rencana selanjutnya tentang kegiatan usaha mereka.

Dengan adanya pendampingan penguatan kegiatan pemasaran produk yang meliputi pemetaan produk yang dibutuhkan oleh sektor rumah tangga, disain foto tampilan promosi produk, dan strategi menarik pembeli, maka jiwa wirausaha ibu-ibu PKK semakin terasah, mereka semakin paham produk-produk apa saja yang dibutuhkan dan diinginkan oleh rumah tangga di sekitar mereka. Bumbu dapur berupa cabai, bawang merah, bawang putih, minyak goreng, gula pasir, telur dan makanan camilan merupakan produk-produk dengan penjualan yang sangat tinggi, karena semua rumah tangga sangat membutuhkan dan menyukai barang-barang tersebut. Demikian 
juga produk-produk yang dianggap dapat meningkatkan kesehatan mereka, yaitu jahe merah, lemon dan madu juga merupakan produk yang cepat laku. Masker juga merupakan barang yang diminati dan dibutuhkan oleh pembeli saat sekarang. Layanan antar barang ke rumah pembeli merupakan strategi untuk menarik pembeli. Pembeli hanya memesan melalui WhatsApp, beberapa saat kemudian produk akan diantar ke rumah, jadi pembeli tidak perlu ke luar rumah untuk mendapatkan barang yang dibutuhkan. Dari hal tersebut menunjukkan bahwa ibu-ibu PKK di Kelurahan Lontar Kota Surabaya sudah memberdayakan diri sendiri menjadi wirausaha (entrepreneur). Hasil dari kegiatan ini adalah : terdapat tambahan pendapatan rumah tangga antara Rp. 200.000 sampai dengan Rp. 500.000 per bulan. Kegiatan pendampingan penguatan tertib administrasi adalah membuat buku catatan yang diperlukan dalam aliran keluar dan masuknya uang dan barang. Dari kegiatan ini membuat para ibu semakin mudah untuk mengelola keluar masuknya uang dan barang. Dari buku catatan itu juga dapat digunakan untuk mencatat barang-barang pesanan dari pembeli, dimana ada kalanya pesanan tersebut merupakan barang yang tidak mereka jual, sehingga penjual berusaha untuk mengadakan barang pesanan pembeli.

\section{KESIMPULAN}

1)Metode yang digunakan untuk menangani masalah ekonomi rumah tangga akibat / dampak pandemi covid 19 yang ada di Kelurahan Lontar Kota Surabaya melalui kegiatan Belanja Antar Tetangga menggunakan metode pelatihan dan pendampingan. a) Metode pelatihan meliputi : pelatihan kewirausahaan, pelatihan pemasaran produk dan pelatihan pembukuan sederhana; b) Metode pendampingan meliputi : pendampingan penguatan kegiatan pemasaran produk dan pendampingan penguatan kegiatan tertib administrasi; 2) Dengan adanya program penyuluhan, pelatihan dan pendampingan tentang kewirausahaan, maka motivasi ibu-ibu PKK untuk melakukan kegiatan berdagang menjadi semakin tinggi. Jiwa entrepreneur semakin tumbuh, mereka semakin bersemangat untuk merintis dan meningkatkan usaha mereka; 3) Penyuluhan dan pendampingan pemasaran produk membuat jiwa wirausaha ibu-ibu PKK semakin terasah, mereka semakin paham produk-produk apa saja yang dibutuhkan dan diinginkan oleh rumah tangga di sekitar mereka. Mereka menawarkan produk yang betul-betul dibutuhkan oleh pembeli. Mereka sudah dapat memetakan produk yang laku jual. Demikian juga tentang strategi pemasarannya, barang apa dan kapan mereka harus menawarkan produk tersebut; 4) Penyuluhan dan pendampingan tertib administrasi telah berhasil menyusun buku catatan tentang keluar dan masuknya uang dan barang yang memudahkan untuk mengontrol kegiatan ekonomi mereka; dan 5) Dari kegiatan Belanja Antar Tetangga diperoleh tambahan pendapatan keluarga sebesar antara $\mathrm{Rp}$. 200.000 sampai dengan Rp. 500.000 per bulan.

\section{SARAN}

1)Bagi ibu-ibu PKK yang menjalankan kegiatan Belanja Antar Tetangga, perlu untuk selalu mengasah jiwa kewirausahaannya. Sehingga ketika ada peluang di depan mereka, hendaknya peluang tersebut ditangkap; 2) Bagi pengurus PKK perlu mewadahi dan memfasilitasi, serta memotivasi anggota PKK untuk selalu bersemangat memberdayakan dirinya dengan cara menghubungkan dengan pihak-pihak yang dapat membantu para ibu PKK untuk mengembangkan usahanya; dan 3) Bagi pihak-pihak terkait, perlu mengadakan pembinaan kepada ibu-ibu PKK dan masyarakat pada umumnya sehingga masyarakat menjadi semakin berdaya.

\section{REFERENSI}

Ananda, Rusydi dan Tien Rafida (2016). Pengantar Kewirausahaan : Rekayasa Akademik Melahirkan Enterpreneurship. Medan : Perdana Publishing.

Indrawati, Mei (2019). Bank Sampah Lontar Mandiri : Pemberdayaan Ibu-Ibu PKK Kelurahan Lontar Kecamatan Sambikerep. 
Prosiding Konferensi Nasional PKM-CSR. Vol. 2

Mubarak, Z. (2010). Evaluasi Pemberdayaan Masyarakat Ditinjau Dari Proses Pengembangan Kapasitas Pada Program PNPM Mandiri Perkotaan di Desa Sastrodirjan Kabupaten Pekalongan. Tesis. Program Studi Magister Teknik Pemberdayaan Wilayah dan Kota. Semarang : Undip.

Sipahelut, Michel (2010). Analisis Pemberdayaan Masyarakat Nelayan di Kecamatan Tobelo kabupaten Halmahera Utara. Tesis. Bogor : IPB.

Shucksmith, Mark. (2013). Future Direction in Rural Development. England : Carnegie UK Trust.

Suharto, E. (2015). Membangun Masyarakat Memberdayakan Rakyat : Kajian Strategi Pembangunan Kesejahteraan Sosial dan Pekerjaan Sosial. Bandung : PT Refika Aditama.

Suryana (2009). Kewirausahaan : Pedoman Praktis, Kiat dan Proses Menuju Sukses. Jakarta : Salemba Empat.

Wijatno (2009). Pengantar Entrepreurship. Jakarta : Grasindo

Zimmerer, T.W., Scarborough, N.M dan Wilson, D. (2009). Essential of Entrepreneurship and Small Business Management. New Jersey : Pearson.

Kompas.com

Rizal, Jawahir Gustav. 29 Mei 2020.

Pandemi Covid-19, Apa Saja Dampak pada Sektor Ketenagakerjaan Indonesia?. 11 Agustus 2020. Kompas.com 

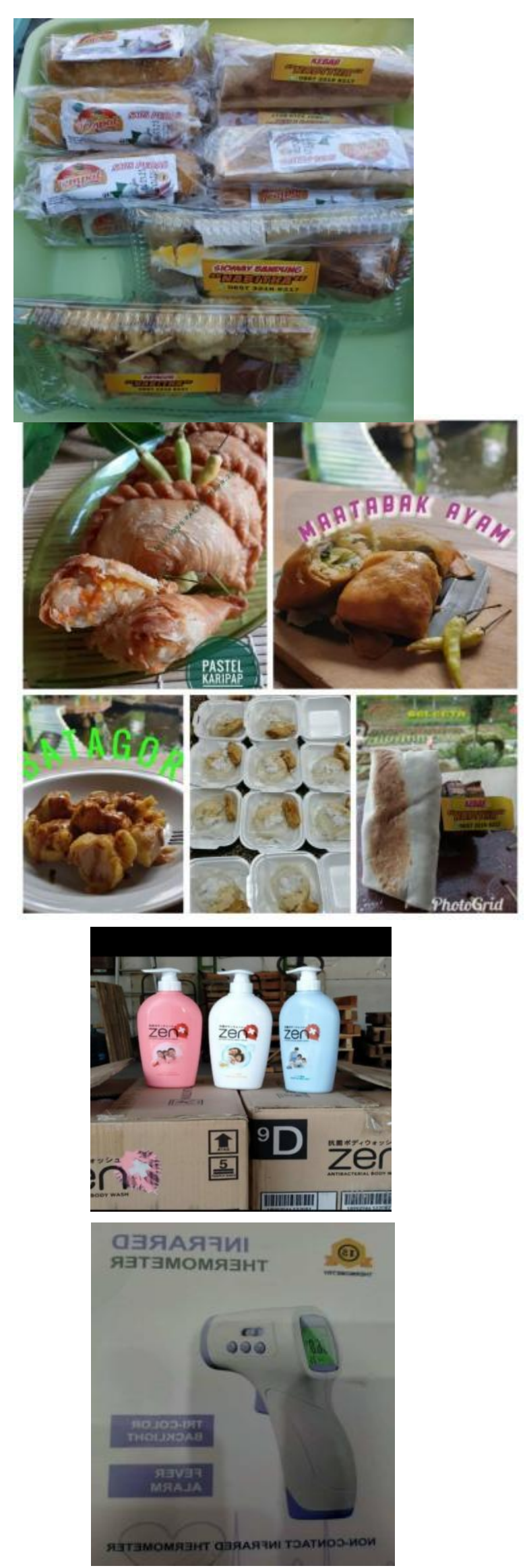

Gambar 2. Barang-Barang yang Ditawarkan melalui WhatsApp pada Kegiatan Belanja Antar Tetangga

Berikut adalah transaksi yang terjadi antara penjual dengan pembeli yang kesemuanya dilakukan di lingkungan Kelurahan Lontar Kota Surabaya. Pembayaran dilakukan secara tunai karena jumlahnya tidak banyak dan lokasinya tidak jauh. Sehingga baik penjual maupun pembeli sama-sama diuntungkan dan sama-sama dimudahkan. Pembeli tidak perlu keluar rumah, karena mereka memesan barang lewat media WhatsApp dan barang diantar ke rumah pembeli. Sementara penjual memperoleh keuntungan dari barang yang dijualnya.

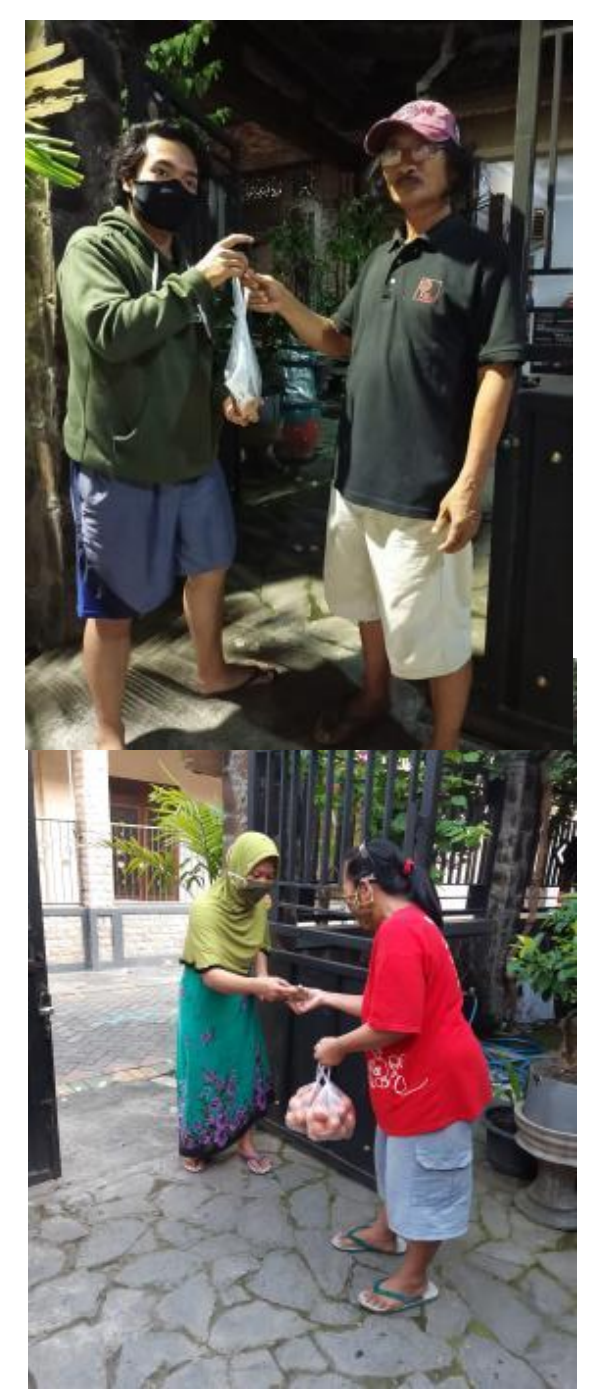

\begin{tabular}{l|l} 
Ekonomi, Sosial, dan Budaya & 1044
\end{tabular} 

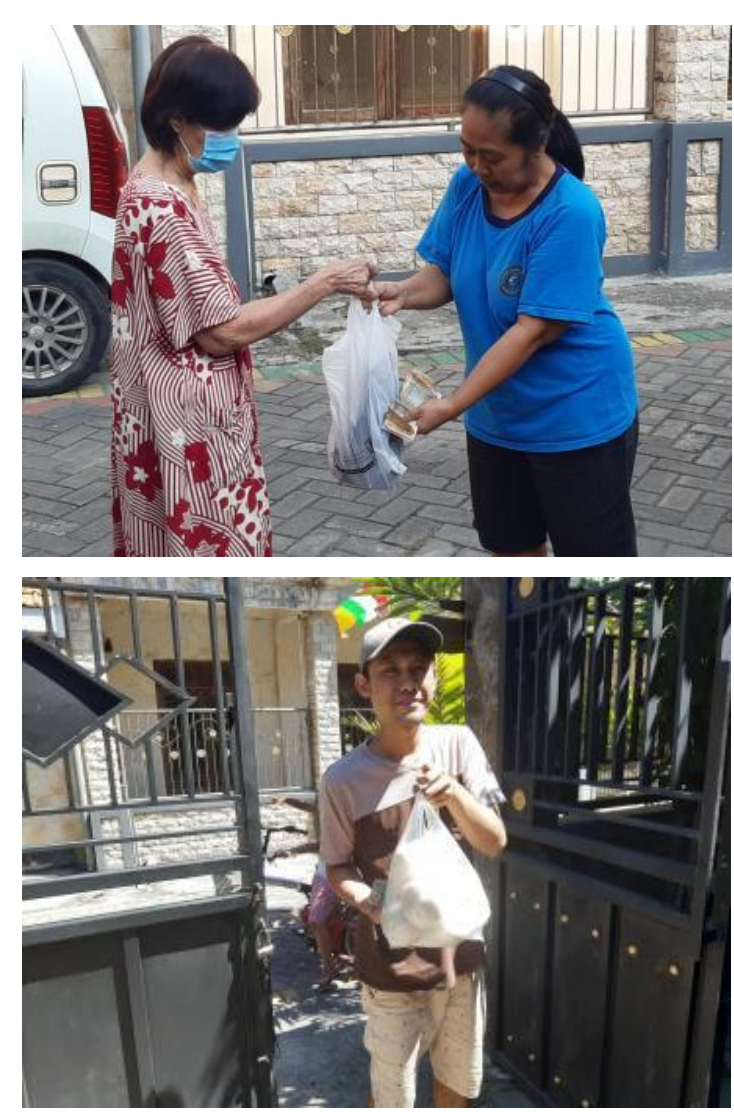

Gambar 3. Transaksi Antar Penjual dan Pembeli

Sisi lain dari adanya kegiatan Belanja Antar Tetangga adalah meningkatnya intensitas bersosialisasi antar warga. Karena barang diantar ke rumah pemesan oleh penjual. Mereka bisa saling menyapa. Dari kegiatan Belanja Antar Tetangga dapat meringankan warga yang kesulitan ekonomi dengan menambah pendapatan rumah tangga antara Rp. 200.000 sampai dengan Rp. 500.000 per bulan. Jadi dengan kegiatan ini telah muncul jiwa wirausaha bagi ibu-ibu PKK Kelurahan Lontar Kota Surabaya. Mereka mampu menangkap peluang yang ada di depan mereka.

Dengan adanya program penyuluhan dan pelatihan tentang kewirausahaan, maka ibu-ibu PKK menjadi semakin termotivasi untuk meningkatkan usaha mereka dengan lebih profesional. Jiwa entrepreneur semakin tumbuh. Hal ini sesuai dengan hasil pengabdian kepada masyarakat yang dilakukan oleh Indrawati (2019). Mereka semakin optimis bahwa dengan Kegiatan Belanja Antar Tetangga dapat meningkatkan pendapatan rumah tangga mereka, sehingga dapat meringankan beban keluarga. Ibu-ibu PKK memiliki tekad bahwa kegiatan ini terus dijalankan meskipun kelak pandemi covid 19 sudah berlalu. Karena mereka sudah merasakan manfaat dari kegiatan yang mereka jalankan selama ini. Penyuluhan tentang pemasaran produk, membuat mereka paham bahwa tidak serta merta mereka menawarkan produknya. Mereka menjual / menawarkan produk dimana barang tersebut memang dibutuhkan / diinginkan oleh banyak keluarga. Sehingga barang mereka cepat terjual dan perputaran modal mereka menjadi cepat. Ujung-ujungnya adalah keuntungan menjadi semakin cepat diperoleh. Penyuluhan pembukuan sederhana juga merubah kinerja mereka, karena dengan semakin tertibnya pencatatan, maka akan semakin mudah untuk mengontrol arus keluar dan masuknya uang dan barang. Berapa uang yang dibelanjakan untuk pengadaan barang dagangan dan berapa uang yang diperoleh dari hasil penjualan per harinya dan kemudian mereka total selama satu minggu satu kali. Dari pencatatan tersebut bisa langsung diketahui berapa keuntungan yang mereka dapatkan. Dari pencatatan sederhana itu juga, mereka dapat membuat rencana selanjutnya tentang kegiatan usaha mereka.

Dengan adanya pendampingan penguatan kegiatan pemasaran produk yang meliputi pemetaan produk yang dibutuhkan oleh sektor rumah tangga, disain foto tampilan promosi produk, dan strategi menarik pembeli, maka jiwa wirausaha ibu-ibu PKK semakin terasah, mereka semakin paham produk-produk apa saja yang dibutuhkan dan diinginkan oleh rumah tangga di sekitar mereka. Bumbu dapur berupa cabai, bawang merah, bawang putih, minyak goreng, gula pasir, telur dan makanan camilan merupakan produk-produk dengan penjualan yang sangat tinggi, karena semua rumah tangga sangat membutuhkan dan menyukai barang-barang tersebut. Demikian juga produk-produk yang dianggap dapat meningkatkan kesehatan mereka, yaitu jahe merah, lemon dan madu juga merupakan produk yang cepat laku. Masker juga merupakan barang yang diminati dan dibutuhkan oleh pembeli saat sekarang. Layanan antar barang ke rumah pembeli

\begin{tabular}{l|l} 
Ekonomi, Sosial, dan Budaya & 1045
\end{tabular} 
merupakan strategi untuk menarik pembeli. Pembeli hanya memesan melalui WhatsApp, beberapa saat kemudian produk akan diantar ke rumah, jadi pembeli tidak perlu ke luar rumah untuk mendapatkan barang yang dibutuhkan. Dari hal tersebut menunjukkan bahwa ibu-ibu PKK di Kelurahan Lontar Kota Surabaya sudah memberdayakan diri sendiri menjadi wirausaha (entrepreneur). Hasil dari kegiatan ini adalah : terdapat tambahan pendapatan rumah tangga antara Rp. 200.000 sampai dengan Rp. 500.000 per bulan. Kegiatan pendampingan penguatan tertib administrasi adalah membuat buku catatan yang diperlukan dalam aliran keluar dan masuknya uang dan barang. Dari kegiatan ini membuat para ibu semakin mudah untuk mengelola keluar masuknya uang dan barang. Dari buku catatan itu juga dapat digunakan untuk mencatat barang-barang pesanan dari pembeli, dimana ada kalanya pesanan tersebut merupakan barang yang tidak mereka jual, sehingga penjual berusaha untuk mengadakan barang pesanan pembeli.

\section{KESIMPULAN}

1)Metode yang digunakan untuk menangani masalah ekonomi rumah tangga akibat / dampak pandemi covid 19 yang ada di Kelurahan Lontar Kota Surabaya melalui kegiatan Belanja Antar Tetangga menggunakan metode pelatihan dan pendampingan. a) Metode pelatihan meliputi : pelatihan kewirausahaan, pelatihan pemasaran produk dan pelatihan pembukuan sederhana; b) Metode pendampingan meliputi: pendampingan penguatan kegiatan pemasaran produk dan pendampingan penguatan kegiatan tertib administrasi; 2) Dengan adanya program penyuluhan, pelatihan dan pendampingan tentang kewirausahaan, maka motivasi ibu-ibu PKK untuk melakukan kegiatan berdagang menjadi semakin tinggi. Jiwa entrepreneur semakin tumbuh, mereka semakin bersemangat untuk merintis dan meningkatkan usaha mereka; 3) Penyuluhan dan pendampingan pemasaran produk membuat jiwa wirausaha ibu-ibu PKK semakin terasah, mereka semakin paham produk-produk apa saja yang dibutuhkan dan diinginkan oleh rumah tangga di sekitar mereka. Mereka menawarkan produk yang betul-betul dibutuhkan oleh pembeli. Mereka sudah dapat memetakan produk yang laku jual. Demikian juga tentang strategi pemasarannya, barang apa dan kapan mereka harus menawarkan produk tersebut; 4) Penyuluhan dan pendampingan tertib administrasi telah berhasil menyusun buku catatan tentang keluar dan masuknya uang dan barang yang memudahkan untuk mengontrol kegiatan ekonomi mereka; dan 5) Dari kegiatan Belanja Antar Tetangga diperoleh tambahan pendapatan keluarga sebesar antara Rp. 200.000 sampai dengan Rp. 500.000 per bulan.

\section{SARAN}

1)Bagi ibu-ibu PKK yang menjalankan kegiatan Belanja Antar Tetangga, perlu untuk selalu mengasah jiwa kewirausahaannya. Sehingga ketika ada peluang di depan mereka, hendaknya peluang tersebut ditangkap; 2) Bagi pengurus PKK perlu mewadahi dan memfasilitasi, serta memotivasi anggota PKK untuk selalu bersemangat memberdayakan dirinya dengan cara menghubungkan dengan pihak-pihak yang dapat membantu para ibu PKK untuk mengembangkan usahanya; dan 3) Bagi pihak-pihak terkait, perlu mengadakan pembinaan kepada ibu-ibu PKK dan masyarakat pada umumnya sehingga masyarakat menjadi semakin berdaya.

\section{REFERENSI}

Ananda, Rusydi dan Tien Rafida (2016). Pengantar Kewirausahaan : Rekayasa Akademik Melahirkan Enterpreneurship. Medan : Perdana Publishing.

Indrawati, Mei (2019). Bank Sampah Lontar Mandiri : Pemberdayaan Ibu-Ibu PKK Kelurahan Lontar Kecamatan Sambikerep. Prosiding Konferensi Nasional PKM-CSR. Vol. 2

Mubarak, Z. (2010). Evaluasi Pemberdayaan Masyarakat Ditinjau Dari Proses Pengembangan Kapasitas Pada Program PNPM Mandiri Perkotaan di Desa Sastrodirjan Kabupaten Pekalongan. Tesis. Program Studi Magister Teknik Pemberdayaan Wilayah dan Kota. Semarang : Undip.

Ekonomi, Sosial, dan Budaya 1046 
Sipahelut, Michel (2010). Analisis Pemberdayaan Masyarakat Nelayan di Kecamatan Tobelo kabupaten Halmahera Utara. Tesis. Bogor : IPB.

Shucksmith, Mark. (2013). Future Direction in Rural Development. England : Carnegie UK Trust.

Suharto, E. (2015). Membangun Masyarakat Memberdayakan Rakyat : Kajian Strategi Pembangunan Kesejahteraan Sosial dan Pekerjaan Sosial. Bandung : PT Refika Aditama.

Suryana (2009). Kewirausahaan : Pedoman Praktis, Kiat dan Proses Menuju Sukses. Jakarta : Salemba Empat.
Wijatno (2009). Pengantar Entrepreurship. Jakarta : Grasindo

Zimmerer, T.W., Scarborough, N.M dan Wilson, D. (2009). Essential of Entrepreneurship and Small Business Management. New Jersey : Pearson.

Rizal, Jawahir Gustav. 29 Mei 2020. Kompas.com

Pandemi Covid-19, Apa Saja Dampak pada Sektor Ketenagakerjaan Indonesia?. 11 Agustus 2020. Kompas.com 